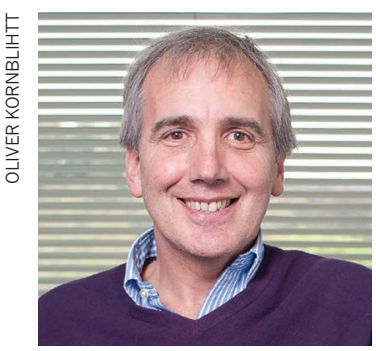

\title{
Where science and nonsense collide
}

\author{
After a decade of progress, Argentina's scientists are battling a government \\ bent on twisting public conceptions of their role, writes Alberto Kornblihtt.
}

$\mathrm{T}$ he government of President Mauricio Macri in Argentina marked its first birthday last month, but there is little to celebrate for scientists.

Unrest in the country made headlines around the world last month when thousands of investigators, graduate students and postdocs occupied the science ministry for five days. That protest ended with palliative concessions from the authorities - the offer of 500 postdoctoral fellowships to those who should have been granted juniorinvestigator positions - but the problems run much deeper.

Macri is the son of a powerful industrialist and a former business partner of US president-elect Donald Trump in property development. The Panama papers, a huge cache of tax files leaked last April, showed that he (and his father and siblings) owned several offshore companies. He is bluntly applying the counterKeynesian plan of opening the economy, reducing the role of the state, increasing foreign debt and creating unemployment to reduce the cost of wages. And - despite his campaign promises to invest - the latest national budget bill pushed by Macri and approved by the Congress for 2017 cut funds for science and technology by $30 \%$.

These brutal cuts are set to reverse a decade of solid investment and progress in Argentinian science. Under previous governments, more than 1,300 young investigators returned to the country and two homemade communications satellites were put into orbit. These administrations also created a ministry for science, technology and productive innovation and built

150,000 square metres of research institutes to house the growing numbers of investigators, graduate students, postdocs and technicians working for the National Council for Scientific and Technological Research (CONICET), the flagship national agency.

The most conspicuous evidence of the current government's approach has been the threat to reduce the number of younginvestigator positions funded by CONICET; it was this that prompted the sit-in protest and it has been only partly addressed.

At the same time, communications satellite programmes have been suspended, and inflation and currency devaluation have reduced the buying power of salaries and research grants.

Scientists in Argentina fear a repeat of the brain drains that the country experienced during times of military rule and economic crisis. Already, colleagues report that young Argentinian scientists in Europe and the United States are having second thoughts about coming home.

The arguments used by ministers and officials to justify the budget cuts are disingenuous and fallacious. Widespread poverty in Argentina, we are now told, makes it unfair and unethical to divert the same amount of money as before to science. (As if poverty did not exist before!) Unlike some countries, Argentina owes its structural poverty not to limited natural or human resources, but rather to a perversely uneven distribution of wealth and a regressive tax system. It seems unfair to punish scientists for such a system, particularly given that President Macri has eliminated export taxes for agriculture and mining, perhaps the two most profitable industries in the country.

It gets worse. Officials have produced a series of provocative statements that threaten the accepted social values of science, research and scholarly pursuits. These statements include: "Investigators should be evaluated by the number of jobs they create and not by the number of papers they publish"; "Each PhD should be encouraged to create his/her own company"; and "CONICET scientists are merely 'paper publishers' who do not return to the society useful applications". One statement even reads: "Young scientists must leave the country", without offering a concomitant government programme to support foreign postdoctoral training.

With such statements, the government is trying to exploit conflict between basic and applied research to sow public distrust of scientists and their work, and to attack the social sciences. This failure to distinguish between the generation of knowledge and the generation of technology is not innocent, and it creates false conceptions about the role of science in society.

Argentina's scientists are proud of their nation's contributions: a strong, fee-less, public university network; two Nobel laureates in science who made their discoveries in Argentina; and seven foreign associates of the US National Academy of Sciences. To call such scientists "paper publishers" is offensive, as if scientific papers were the final aim of research rather than the means through which to make relevant findings public.

To complete the landscape of nonsense, the chief of the cabinet of ministers, Marcos Peña, attacked one of the fundamentals of science by saying that "critical thinking has done too much damage to our country". He continued: "Some people in Argentina think that being critical is being smart. Our government believes that being smart is being enthusiastic and optimistic."

This is gobbledygook, yet it neatly fits the New Age concept of the "revolution of happiness" proclaimed by Macri as a lubricant for social conflicts. Colleagues around the world should know that, in this new Argentina, science and technology could become dispensable. More demonstrations are sure to follow. We will not give up our scientific heritage and future without a fight..

Alberto Kornblihtt is professor of molecular biology at the Faculty of Exact and Natural Sciences at the University of Buenos Aires, and a CONICET investigator.

e-mail:ark@fbmc.fcen.uba.ar 